\title{
Land Use and Climate Change
}

According to Roger Pielke Sr., a leading authority on land-use change, "change and variability in land use by humans and the resulting alterations in surface features are major but poorly recognized drivers of long-term global climate patterns ... these spatially heterogeneous land use effects may be at least as important in altering the weather as changes in climate patterns associated with greenhouse gases."1

NASA reports that between one-third and one-half of our planet's land surfaces have been transformed by human development.

Experiments by Feddema et al. using the USDOE Parallel Climate Model (DOEPCM) showed how land use changes altered the climate change simulations, and should be considered a first order climate forcing factor.

Man alters the planet surfaces in diverse ways trough urbanization, suburbanization, deforestation, foresting former grasslands, irrigating desert land for crops, damming rivers to create man-made lakes and reservoirs, land-filling swamps and marshlands, etc.

These factors affect the climate on scales ranging from the macroscale to the microscale.

One example of how land use and land cover affects global climate is the changing spatial and temporal pattern of thunderstorms. Deforestation or urbanization may influence the nature of the heat fluxes and availability of water vapor. Deforestation in central Africa and South America may have played a role in the shifting of the thunderstorms associated with the ITCZ.

The accelerated shrinking of the glacier atop Mt Kilamanjaro is thought to be associated with a combination of Atlantic Multidecadal Cycle changes and land use (deforestation) in Africa. Temperatures in that region have been declining for the past 25 years, so the melting of the Kliamanjaro glacier is not related to global warming but these other factors. 
Kilimanjaro

Alike

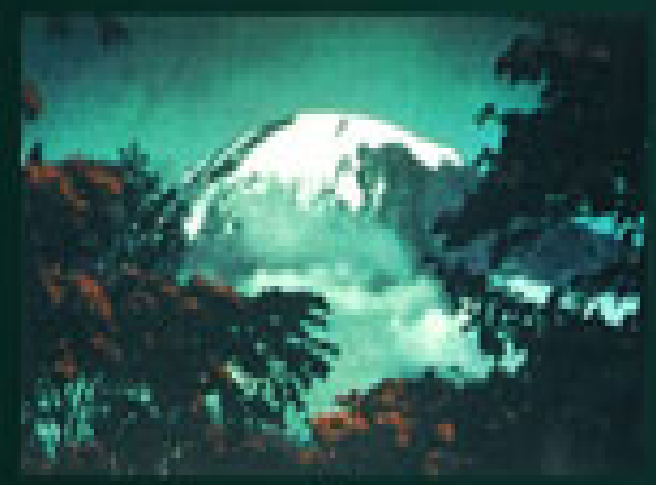

170

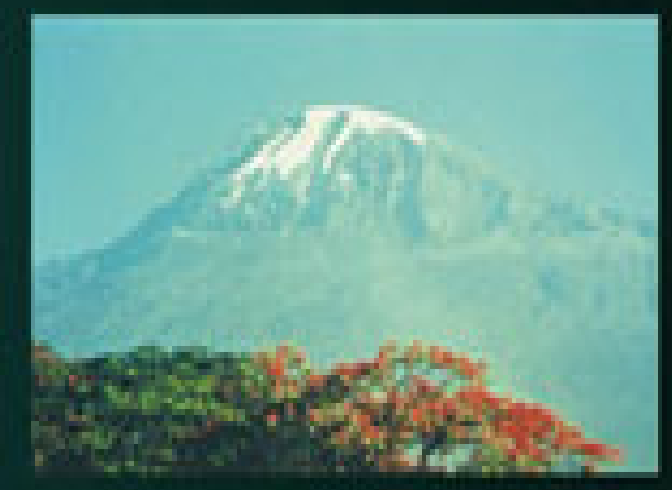

200

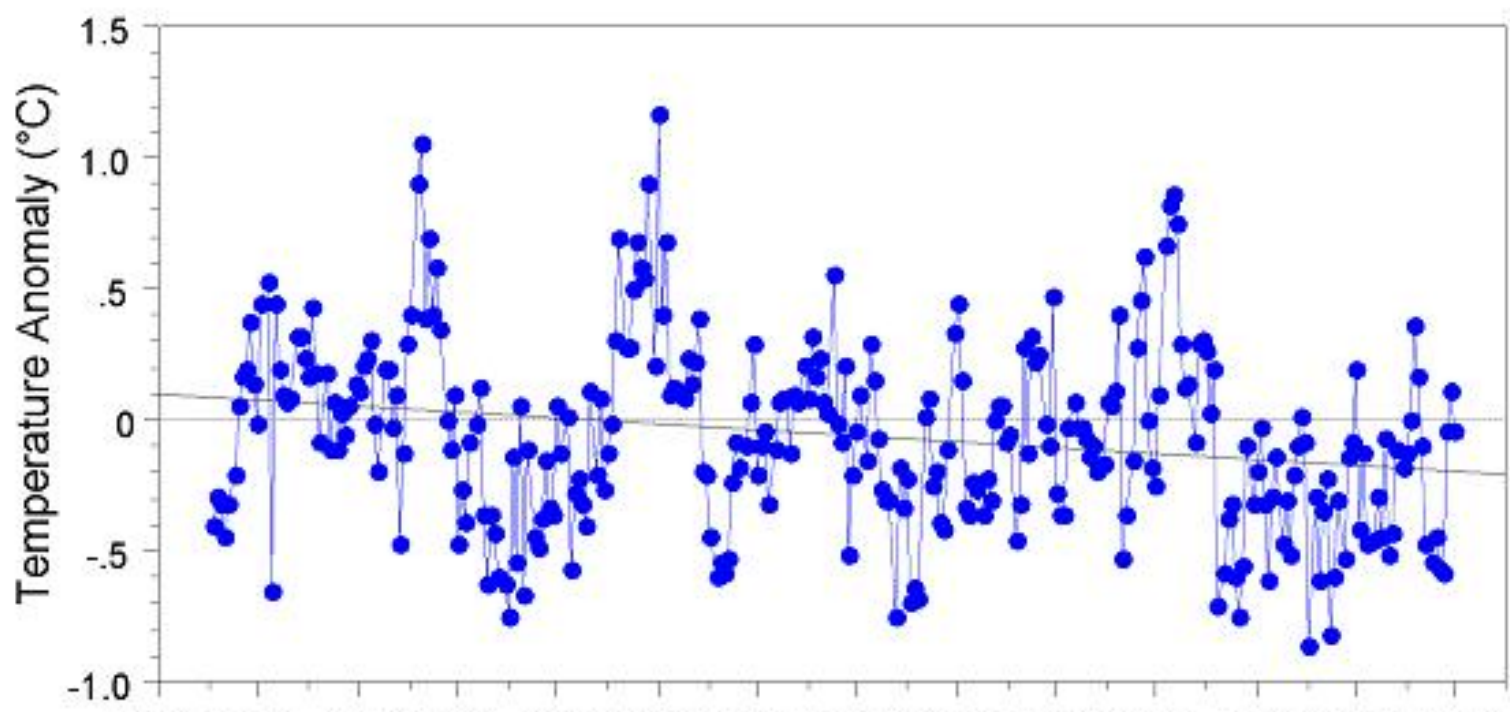

19781980198219841986198819901992199419961998200020022004 Year 
Temperatures have been declining at Kilamanjaro since the late 1970s during the satellite era. Precipitation during this same period has been below normal.

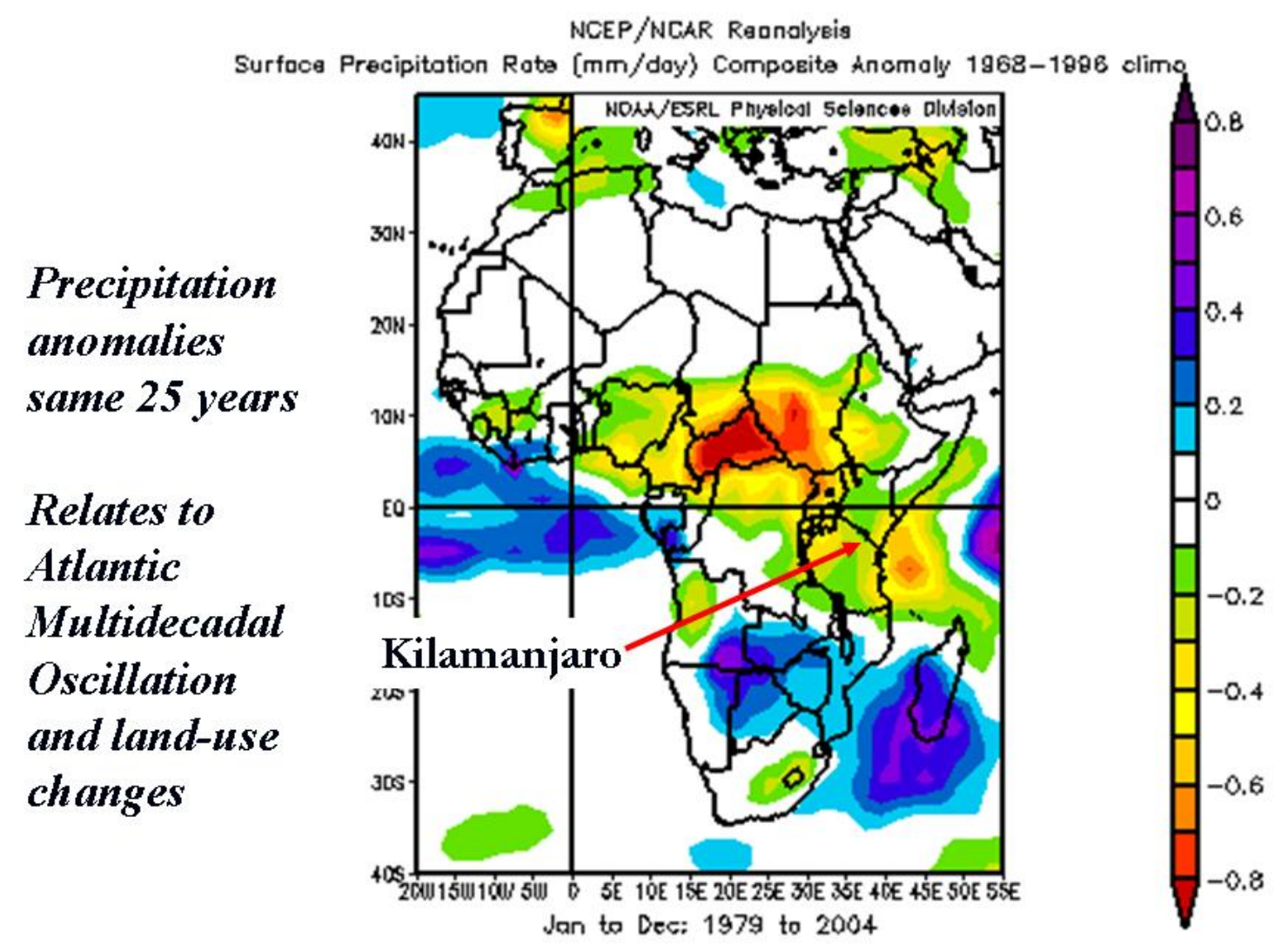

Since most of the world's thunderstorms occur over land (about 10 to 1), the changes we make to the land surface will have a proportionally greater influence on climate than is represented by the fraction of the area that land covers. When spatial differences in thunderstorms occur, it can affect the atmospheric circulation systems and affect weather and climate.

Jim Hansen of NASA estimated that $25 \%$ of the $20^{\text {th }}$ century warming could be coming from soot on snow (which is a land-use change).

On a smaller scale, land use changes influence local temperatures In a BAMS 2005 paper, Pielke and Davey noted issues with siting with the majority of 57 coop stations (10 which were part of the USHCN network for climate assessment. In many cases, the temperature sensors did not meet the WMO 1996 requirements for proper siting. Though Peterson responded (2006) that he can adjust poorly sited stations of this type, Pielke (2006) showed that no value is added from such sites. In addition, for locations where these poorly sited locations are the only data used to construct a grid area average in the global temperature trend data base, their use will introduce spatially unrepresentative data into the analyses. . Kalnay and Kai (2003) estimated $40 \%$ of the global temperature rises is coming from land use changes, Marland estimated 50\%. 
Additional studies conducted for NOAA in Georgia and New England uncovered similar anomalies in siting that make some of the climate sites unsuitable for climate change studies without proper adjustment. The Oklahoma mesonet, the gold standard for observing networks, conducted a survey of their own network, which were meticulously set up to meet WMO standards and found even there with time factors changed. One site had small cedar bushes to the west grow into large cedar trees affecting both the wind and temperature profiles.

This factor overlaps with Urban Heat Island effect

\section{References}

Christy, J. R. And R. W. Spencer, 2004. 25 years of satellite data show Â\&euro ;global warming' of only 0.34 . Press release, University of Alabama, Huntsville, AL (http://uahnews.uah.edu/scienceread.asp?newsID=196).

Christy, J. R., R. W. Spencer, W. B. Norris, W. D. Braswell and D. E. Parker, 2003. Error estimates of Version 5.0 of MSU/AMSU bulk atmospheric temperatures. Journal of Atmospheric and Oceanic Technology, 20, 613-629.

Davey, C.A., and R.A. Pielke Sr. (2005) "Microclimate Exposures of Surface-based Weather Stations - Implications for the Assessment of Long-term Temperature Trends." Bulletin of the American Meteorological Society 86(4) 497-504

De Laat, A.T.J., and A.N. Maurellis (2004). "Industrial CO2 Emissions as a Proxy for Anthropogenic Influence on Lower Tropospheric Temperature Trends.” Geophysical Research Letters Vol. 31, L05204, doi:10.1029/2003GL019024.

De Laat, A.T.J., and A.N. Maurellis (2006). "Evidence for Influence of Anthropogenic Surface Processes on Lower Tropospheric and Surface Temperature Trends." International Journal of Climatology 26:897-913.

Hansen, J., Sato, M. and Ruedy, R. 1995. Long-term changes of the diurnal temperature cycle: Implications about mechanisms of global climate change. Atmospheric Research, 37, 175-209.

Hansen, J., and L. Nazarenko 2003. Soot climate forcing via snow and ice albedos. Proc. Natl. Acad. Sci., 101, 423-428.

Hoyt, Doug, Urban heat Islands and Land Use Changes http://www.warwickhughes.com/hopyt/uhi.htm

Jones, P. D. and A. Moberg, 2003. Hemispheric and Large-Scale Air Temperature Variations: An Extensive Revision and Update to 2001. Journal of Climate, 16, 206-223. 
Jones, P.D., P. Ya. Groisman, M. Coughlan, N. Plummer, W-C. Wang and T.R. Karl (1990). "Assessment of Urbanization Effects in Time Series of Surface Air Temperature Over Land.” Nature 347 169-172.

Karl, T.R., H.F. Diaz, and G. Kukla, 1988: Urbanization: its detection and effect in the United States climate record, J. Climate, 1, 1099-1123.

Li, Q. et al., 2004: Urban Heat Island Effect on Annual Mean Temperatures during the Last 50 Years in

China. Theor. Appl. Climatol., 79, 165-174.

Kalnay, E. and M. Cai, 2003. Impact of urbanization and land-use change on climate. Nature 423, 528 - 531

Mann, M. E., Bradley, R. S. and Hughes, M. K. 1998. Global-scale temperature patterns and climate forcing over the past six centuries. Nature, 392, 779-787.

Marland, G., R. A. Pielke, Sr., M. Apps, R. Avissar, R.A. Betts, K.J. Davis, P.C. Frumhoff, S.T. Jackson, L. Joyce, P. Kauppi, J. Katzenberger, K.G. MacDicken, R. Neilson, J.O. Niles, D. dutta S. Niyogi, R.J. Norby, N. Pena, N. Sampson, and Y. Xue, 2003. The climatic impacts of land surface change and carbon management, and the implications for climate-change mitigation policy. Climate Policy, accepted.

McIntyre, S. and McKitrick, R. 2003. Corrections to the Mann et al. (1998) proxy data base and Northern Hemispheric average temperature series. Energy and Environment,14, 751-771.

Molg, T., D. R. Hardy, and G. Kaser, 2003. Solar-radiation-maintained glacier recession on Kilimanjaro drawn from combined ice-radiation geometry modeling, J. Geophys. Res., 108, 4731.

Oke, T.R. 1973. City size and the urban heat island. Atmospheric Environment, 7 769779.

Pielke, R. A., Sr., J. Eastman, T. N. Chase, J. Knaff, and T. G. F. Kittel, 1998. The 19731996 trends in depth-averaged tropospheric temperature, J. Geophys. Res., 103, 16,92716,933 .

Peterson, 2005, Examination of potential biases in air temperature caused by poor station locations. Bull. Amer. Meteor. Soc., 87, 1073-1089

Pielke, R. A., Sr., J. Eastman, T. N. Chase, J. Knaff, and T. G. F. Kittel, 1998. Correction to "The 1973-1996 trends in depth-averaged tropo-spheric temperature," J. Geophys. Res., 103, 28, 909-911.

Pielke, R. Sr., 2005 Land use and Climate Change, Science, 310 
Santer, B. D., et al., 2000. Interpreting differential temperature trends at the surface and in the lower troposphere. Science, 287, 1227-1232.

Torok, S. J., Morris, C. J. G., Skinner, C. and Plummer, N. 2001. Urban heat island features of southeast Australian towns. Australian Meteorological Magazine, 50, 1-13.

Jones, P.D., P. Ya. Groisman, M. Coughlan, N. Plummer, W-C. Wang and T.R. Karl (1990). "Assessment of Urbanization Effects in Time Series of Surface Air Temperature Over Land.” Nature 347 169-172.

Karl, T.R., H.F. Diaz, and G. Kukla, 1988: Urbanization: its detection and effect in the United States climate record, J. Climate, 1, 1099-1123.

Li, Q. et al., 2004: Urban Heat Island Effect on Annual Mean Temperatures during the Last 50 Years in China. Theor. Appl. Climatol., 79, 165-174.

McKendry, Ian G. (2003) "Progress Report: Applied Climatology" Progress in Physical Geography 27(4) pp. 597-606

McKitrick, R and P. J. Michaels (2004). "A Test of Corrections for Extraneous Signals in Gridded Surface Temperature Data" Climate Research 26(2) pp. 159-173. "Erratum," Climate Research 27(3) 265-268.

Parker, D.E. (2004). “Climate: Large-Scale Warming is not Urban.” Nature 432, 290 (18 November 2004); doi:10.1038/432290a.

Peterson T.C. and R.S. Vose (1997) "An Overview of the Global Historical Climatology Network Temperature Database." Bulletin of the American Meteorological Society $78: 28372849$.

Peterson, T.C. (2003). "Assessment of Urban Versus Rural in situ Surface Temperatures in the Contiguous United States: No Difference Found." Journal of Climate 16(18) $2941-2959$.

Peterson, 2006 Examination of potential biases in air temperature caused by poor station locations. Bull. Amer. Meteor. Soc., 87, 1073-1089

Pielke R.A. Sr., G. Marland, R.A. Betts, T.N. Chase, J.L. Eastman, J.O. Niles, D.D.S. Niyogi and S.W. Running. (2002) "The Influence of Land-use Change and Landscape Dynamics on the Climate System: Relevance to Climate-Change Policy Beyond the Radiative Effect of Greenhouse Gases." Philosophical Transactions of the Royal Society of London. A360:1705-1719

Pielke, RA Sr. and T. Matsui (2005) "Should Light Wind and Windy Nights have the Same Temperature Trends at Individual Levels Even if the Boundary Layer Averaged 
Heat Content Change is the Same?" Geophysical Research Letters (32) L21813, doi:10.1029/2005GL024407, 2005.

Pielke, R.A., Sr, 2003. Heat Storage Within the Earth System, BAMS, March, 331-335.

Pielke Sr., R.A, J. Nielsen-Gammon, C. Davey, J. Angel, O. Bliss, M. Cai, N. Doesken, S. Fall, K. Gallo, R. Hale, K.G. Hubbard, H. Li, X. Lin, , D. Niyogi, and S. Raman, 2006: Documentation of bias associated with surface temperature measurement sites, submiteed to BAMS

Willmott, C. J., S. M. Robeson and J. J. Feddema, 1991. Influence of Spatially Variable Instrument Networks on Climatic Averages. Geophysical Research Letters, 18(12), 2249-2251.

\section{Expert Contact:}

Roger Pielke Sr';s Climate Science web log

http://climatesci.atmos.colostate.edu/category/climate-change-forcings-and-feedbacks/

Roger A. Pielke Sr.

Senior Research Scientist

Email: pielkesr@cires.colorado.edu

970-491-8293 (phone)

970-491-3314 (fax)

Other recommended links:

Hoyt, Doug, Urban heat Islands and Land Use Changes

http://www.warwickhughes.com/hopyt/uhi.htm 